\title{
(@) Reflexões sobre Professoralidade, Profissionalização, Profissionalidade, Profissionalismo e sua relação com o Desenvolvimento Profissional Docente
}

\author{
Cláudio César Torquato Rocha * \\ Adriana Teixeira Bastos **
}

\begin{abstract}
Resumo: Várias são as categorias teóricas que guardam relação com o tema desenvolvimento profissional docente (DPD). Professoralidade, profissionalização, profissionalismo são algumas delas, mas geralmente não aparecem conjuntamente nem em relação do DPD. Por isto, este trabalho visa a analisar estes conceitos em relação ao DPD. A investigação foi desenvolvida a partir de metodologia baseada na pesquisa bibliográfica. Os argumentos evidenciaram que o DPD, na atualidade, perpassa questões da professoralidade, da profissionalização, da profissionalidade e do profissionalismo, mesmo que em intensidades diferentes. Profissionalidade e professoralidade são aqueles que mais dizem respeito a uma estreita vinculação com o desenvolvimento profissional docente por se relacionarem de forma imbricada sem que se possa separar um do outro, ao passo que no profissionalismo e na profissionalização não existe uma relação de complementariedade ou espontânea, mas sem dúvida ambos os lados da relação podem se beneficiar um do outro.
\end{abstract}

Palavras-chave: Desenvolvimento Profissional Docente, Professoralidade, Profissionalização, Profissionalidade, Profissionalismo.

\footnotetext{
* Doutor em Educação pela Universidade Estadual do Ceará (UECE). Professor na Universidade Estadual do Ceará (UECE). E-mail: claudio_torquato@yahoo.com.br. ORCID: https://orcid.org/0000-0001-6691-804X. Doutora em Administração de Empresas pela Universidade de Fortaleza (UNIFOR).

*** Professora na Universidade Estadual do Ceará (UECE).E-mail: adriana.bastos@uece.br. ORCID: https://orcid.org/0000-0003-3789-9956.
} 


\title{
Reflections on professorality ${ }^{1}$, professionalization, professionality, professionalism and its relationship with the teacher professional development
}

\begin{abstract}
There are several theoretical categories that are related to the theme of teacher professional development (TPD). Professionality, professionalism, professorship, professionalization are some of them, but generally do not appear together in relation to the TPD. For this reason, this work aims to analyze these concepts in relation to the TPD. The investigation was developed based on a bibliographic research methodology. The arguments showed that the TPD, at present, runs through issues of teaching, professionalism, professionalism and professionalization, even if at different intensities. Professorship and professionality are those that most relate to a close link with the professional development of teachers because they relate in an interconnected way without being able to separate from each other, whereas in professionalism and professionalization there is no complementary or spontaneous relationship, but no doubt both sides of the relationship can benefit from each other.
\end{abstract}

Keywords: Teacher Professional Development, Professorship, Professionalization, Professionality, Professionalism.

\section{Reflexiones sobre Profesoralidad, profesionalización, profesionalidad, profesionalismo y su relación con el desarrollo profesional de los docentes.}

Resumen: Existen varias categorías teóricas relacionadas con el tema del desarrollo profesional docente (DPD). Profesoralidad, profesionalización, profesionalidad, profesionalismo son algunos de ellos, pero generalmente no aparecen juntos o en relación con el DPD. Por esta razón, este trabajo tiene como objetivo analizar estos conceptos en relación con el DPD. La investigación se desarrolló en base a una metodología basada en la investigación bibliográfica. Los argumentos mostraron que el DPD, en la actualidad, atraviesa problemas de

\footnotetext{
${ }^{1}$ Em português parece não existir consenso quanto à tradução do termo "Professoralidade". Consultando outros artigos, encontramos os termos: teaching action approach, professorialism, professorship, Teaching Practice, professor practice, professorality e professorship. Desta forma, optamos pelo termo "professorality", até para proporcionar paralelismo à tradução que elegemos para o termo "Profissionalidade", que parece também não encontrar tradução que seja consenso, pois também encontramos os seguintes termos na literatura disponível: professionality, professionalism, professional e professionality.
} 
enseñanza, profesionalización, profesionalismo y profesionalismo, incluso a diferentes intensidades. La profesionalidad y la enseñanza son las que más se relacionan con un vínculo cercano con el desarrollo profesional de los docentes porque se relacionan de manera interconectada sin poder separarse entre sí, mientras que en el profesionalismo y la profesionalización no existe una relación complementaria o espontánea. Pero sin duda ambos lados de la relación pueden beneficiarse el uno del otro.

Palabras clave: Desarrollo profesional docente, profesoralidad, profesionalización, profesionalidad, profesionalismo.

\section{Introdução}

Observamos que várias são as categorias teóricas que guardam relação direta com o debate sobre o tema desenvolvimento profissional docente (DPD) ${ }^{2}$. Algumas delas, conforme levantamento realizado por nós, dizem respeito aos termos profissionalidade, profissionalismo, profissionalização e professoralidade. Ainda que estas categorias apareçam com certa frequência nas produções científicas brasileiras dos últimos anos, elas não ocorrem com a mesma constância e nem ocupam o mesmo lugar de importância no ranking das categorias do debate educacional e, tampouco, aparecem conjuntamente. Por isto, dedicamo-nos a refletir sobre estas quatro categorias de forma interligada, tendo como referencial de discussão sua relação com o DPD. O mote norteador de discussão deste trabalho é apresentado com a seguinte questão: que relações podem ser

\footnotetext{
${ }^{2}$ Neste ensaio, entendemos DPD como "um conjunto de fatores que possibilitam ou impedem que o professorado avance na identidade. A melhoria da formação e a autonomia para decidir contribuirão para esse desenvolvimento, porém, a melhoria de outros fatores (salário, estruturas, níveis de decisão, níveis de participação, carreira, clima de trabalho, legislação trabalhista) também o farão e de forma muito decisiva. Podemos realizar uma excelente formação e depararmos com o paradoxo: um desenvolvimento próximo à proletarização no professorado porque os outros fatores não estão suficientemente garantidos nessa melhoria. E isso repercute, é claro, no desenvolvimento profissional, mas também muito no desenvolvimento pessoal e na identidade" (IMBERNÓN, 2009, p. 77$78)$.
} 
observadas entre DPD e os termos professoralidade, profissionalidade, profissionalismo e profissionalização, considerando o contexto sóciohistórico que vivemos? Assim sendo, este trabalho, visa realizar análise das relações entre DPD e as categorias acima identificadas e consideradas como elementos relevantes para compreender a realidade dos professores da Educação Básica no Brasil.

Outrossim, cabe ressaltar, que as ponderações aqui desenvolvidas, constituem-se em parte de uma pesquisa de doutoramento em Educação, realizado entre 2014 e 2018, que tinha com objeto de investigação a formação continuada de professores da Educação Básica no contexto do Programa Institucional de Bolsa de Iniciação a Docência (PIBID) ${ }^{3}$.

A investigação foi desenvolvida a partir de metodologia baseada na pesquisa bibliográfica (MENDES; FARIAS; NÓBREGA-THERRIEN, 2011). Pesquisa bibliográfica é aquela desenvolvida com base em material já elaborado, constituído de livros, publicações periódicas e impressos diversos. É um tipo de pesquisa indispensável para todos os tipos de pesquisa, pois vale-se fundamentalmente das análises e contribuições de diversos autores, diferentemente da pesquisa documental, que se utiliza de materiais que ainda não receberam tratamento analítico, ou que podem ser reelaborados conforme o objeto da pesquisa.

Sendo assim, além desta introdução, desenvolvemos este artigo partindo da compreensão do contexto em que surgem estes termos, para em seguida desenvolvermos a compreensão conceitual do que vem a ser professoralidade, profissionalidade, profissionalismo e profissionalização em relação ao DPD. Por fim, concluímos nossas reflexões com as considerações finais.

\footnotetext{
${ }^{3} \mathrm{O}$ PIBID é uma política pública que tem por finalidade "fomentar a iniciação à docência, contribuindo para o aperfeiçoamento da formação de docentes em nível superior e para a melhoria de qualidade da educação básica pública brasileira" (BRASIL/CASA CIVIL DA PRESIDÊNCIA, 2010).
} 


\section{Um contexto líquido por vocação}

Cabe começar lembrando que as categorias e conceitos aqui estudados despontam, desenvolvem-se e desaparecem no tempo. São instrumentos interpretativos, criados pelos sujeitos para tentar compreender a realidade de um determinado momento. Deste modo, seria impossível conjecturar sobre DPD no período do chamado descobrimento do Brasil, porque o fenômeno inexistia naquela realidade, como também não materializava na realidade dos samurais, no Japão, tampouco no surgimento do renascimento europeu.

Convêm, ainda, destacar que a discussão sobre DPD apareceu quase que simultaneamente aos primeiros processos desencadeados pela terceira revolução industrial, normalmente conhecida como a revolução científica e tecnológica iniciada nos anos 1970, cuja força foi demonstrada, vigorosamente por meio de inovações, de 1980 a 2000 (JAPPE, 2013). Para ser mais preciso, a discussão iniciou-se na primeira metade dos anos 1980, nos Estados Unidos, por meio do debate sobre profissionalização e formação dos professores (POPKEWITZ, 1992; ROCHA, 2018).

Para efeito de entendimento do que seja DPD, adotamos a compreensão de que se referem ao resultado de um processo contínuo num contextual social e político situado em que os professores se implicam de forma a buscar melhorias para si e para a comunidade escolar, em particular para os discentes. Diz respeito, entre outros elementos, a possibilitar o desenvolvimento de habilidades, atitudes e crenças condizentes com a mudança da cultura docente e escolar via o equacionamento de suas demandas através da elaboração de um novo projeto pedagógico e a colaboração dos fatores como o salarial e o estrutural, os níveis de deliberação e de engajamento, o clima de trabalho, a benfeitoria na carreira e na legislação trabalhista (FARIAS; ROCHA, 2016).

Mais recentemente, novos processos, ocorridos com o avanço dos conhecimentos científicos e tecnológicos disponíveis e empregados na produção e distribuição das riquezas sociais, fizeram deslanchar a chamada 
Reflexões sobre Professoralidade, Profissionalização, Profissionalidade, Profissionalismo e sua relação com o Desenvolvimento Profissional Docente

quarta revolução industrial (SCHWAB, 2016). Estes processos estão associados aos avanços que tocam os conhecimentos no campo da nanotecnologia, engenharia genética, computação quântica, combustíveis renováveis, robótica, inteligência artificial, impressão em três dimensões (3D), fármacos sintéticos, cibernética, tecnologias digitais da informação e comunicação, entre outros.

Em linhas gerais, podemos dizer que, enquanto a terceira revolução industrial inaugurou novos inventos e revolucionários usos como os microcomputadores e os chips, os dispositivos móveis atuais com suportes de internet, agenda eletrônica, e-mail, TV digital, rádio, gravador de voz, câmera filmadora, entre outras centenas de aplicativos concentrados, a quarta revolução industrial fez com que estes dispositivos se comunicassem entre si, dando origem à chamada internet das coisas, em que tudo se tornou simultaneamente interconectado, ilimitado e acessível a quem puder pagar. Esclarece Schwab (2016, p.16) que "o que torna a quarta revolução industrial fundamentalmente diferente das anteriores é a fusão dessas tecnologias e a interação entre os domínios físicos, digitais e biológicos".

Refletindo sobre o tempo entre as revoluções industriais da História, verificamos que o período de tempo, transcorrido do início da segunda revolução industrial (aproximadamente em 1850) até o começo da terceira (aproximadamente em 1960), foi de mais de cem anos. Já entre o início da terceira revolução industrial e o começo da quarta (ocorrido provavelmente em 2011 ${ }^{4}$ ), foi equivalente à metade do mesmo tempo cronológico que separou as revoluções industriais anteriores.

Revoluções, como as mencionadas, pressupõem sempre e, anteriormente, a existência de crises. Vivemos no atual momento: crise na maneira de produzir e consumir, refletida na ampliação da riqueza social e pessoal e, ao mesmo tempo, no colapso ambiental (MARQUES, 2015); crise nos relacionamentos interpessoais e intrapessoais, expandindo várias configurações de família e outras subjetividades, acarretando subsequentes

\footnotetext{
${ }^{4}$ Schwab (2016) adverte que em 2011 a discussão sobre a "indústria 4.0" teve início na Alemanha, mais precisamente na feira de Hannover daquele ano.
} 
contestações da parte dos segmentos sociais mais conservadores; crise de valores e crenças, que nos tem feito caracterizar este momento histórico como o das incertezas, marcadas, por um lado, por momentos de extremas ilusões fetichistas e, por outro, por um profundo sentimento de vazio e tédio; crise no modelo de fazer ciência e início da transição de novas perspectivas do conhecimento, baseada na complexidade e na solidariedade (SANTOS, 2002; 2010); crise dos fundamentos da sociedade baseada no trabalho ${ }^{5}$ e seus modelos (democrático/autoritário) de representação política (JAPPE, 2013) e, por conseguinte, a "crise do profissionalismo" (TARDIF, 2010, p.252). Crise, resumindo, é a palavrachave sob a qual as últimas gerações foram socializadas e cuja cultura reflete um padrão, vamos dizer: líquido ${ }^{6}$ (BAUMAN, 2001), que tem deixado, sobretudo, os indivíduos das gerações mais antigas, muitas vezes em choque ao observar certos comportamentos cotidianos que seriam inaceitáveis em épocas anteriores.

A título de exemplo, vamos trazer uma passagem da escrita de Jappe (2013, p. 91) sobre alguns comportamentos que contextualiza o momento que estamos vivendo que este autor chamou de "regressão antropológica". Vejamos:

\footnotetext{
5 Trabalho é entendido aqui como conceituado por Jappe (2013, p. 88), ao argumentar que, "criticar o trabalho não teria nenhum sentido se o identificássemos com a atividade produtiva enquanto tal, que decerto, é um dado presente em toda sociedade humana. Mas tudo muda quando entendemos por trabalho aquilo que a palavra designa efetivamente na sociedade capitalista: o dispêndio autorreferencial de simples força de trabalho sem relação com seu conteúdo. Assim concebido, o trabalho é um fenômeno histórico, pertencente apenas à sociedade capitalista, portanto, pode ser criticado e eventualmente abolido. Com efeito, o 'trabalho', que todos os atores do campo político querem salvar, tanto à esquerda, como à direita e ao centro, é o trabalho entendido em seu sentido restrito.

${ }^{6}$ Bauman (2001), sociólogo polonês recentemente falecido, diz que na modernidade líquida, período em que vivemos, prevalecem as relações humanas fluídas, que escorrem entre os dedos, vazam e transbordam como o líquido, por não ter uma configuração definitiva, mas que se acomodam conforme o recipiente nos quais estão contidos. Diferente da modernidade anterior, vivida de maneira sólida e que para as alterações vingarem precisavam que tensões de força fossem mobilizadas para acomodarem a novas configurações.
} 
O contexto é doravante o de uma verdadeira mutação antropológica que tanto é o resultado de mais de duzentos anos de capitalismo quanto de sua destruição programada que se tornou visível desde há algumas décadas. Esta regressão se estende até a barbarização. Em face da multiplicação de casos como o de adolescentes que filmam, rindo, com seus celulares, uma colega que acaba de ser morta por um ônibus, para colocar em seguida as imagens no Youtube, não basta evocar o desemprego, a precariedade ou os defeitos da escola: estamos assistindo a uma 'regressão generalizada' (o que não quer dizer uniforme). (Grifo do autor).

O mais impressionante desta realidade globalizada, é que tudo isso parece ocorrer numa rapidez cada vez mais próxima da velocidade da luz, tendo por isso, provocado mudanças profundas em nossa cultura e em cada um de nós, de modo a tirar, muitas vezes, o chão sob os pés. Também fatos ocorridos do outro lado do mundo repercutem em segundos em nosso cotidiano, com ilações diversas e difíceis de serem assimiladas ${ }^{7}$.

Noutras palavras, o queremos dizer com esta contextualização é que a noção de tempo e espaço foi, mais uma vez, socialmente redimensionada. Assim, uma coisa era ser professor no período anterior à Primeira Guerra Mundial (1914-1918) na Europa e outra bem diferente é ser professor no Brasil de hoje, com as políticas educacionais internacionalizadas (AKKARI, 2011) e ao mesmo tempo com a justaposição da crise e iminência do colapso de todo o sistema produtor de

\footnotetext{
${ }^{7}$ Referimo-nos, por exemplo, ao retorno do fascismo no mundo. Na Europa, Marine Le Pen foi candidata do partido da extrema direita, escolhida para concorrer no segundo turno da eleição presidencial na França, em 2017; nos Estados Unidos, fascistas saem em passeatas, como a ocorrida recentemente (julho de 2017) na pequena cidade de Charlottesville, no estado de Virgínia. No Brasil e no momento que escrevemos este trabalho somos informados, pela mídia, sobre o resultado da eleição de Jair Bolsonaro, candidato do Partido Social Liberal (PSL), organização política da estrema direita, como presidente do Brasil.
} 
mercadorias (JAPPE, 2013), sinalizada por meio da barbarização das relações sociais em curso ${ }^{8}$.

Este é o mundo que habitamos e que tem nos configurados. Somos produtos e criamos esta realidade, tenhamos ou não consciência disso. Sobre isso, Jappe (2013) esclarece que na sociedade mercantil somos regidos pela lógica do fetichismo da mercadoria e esclarece, como segue:

O 'fetichismo da mercadoria' deve ser entendido ao pé da letra: os homens modernos - assim como aqueles nomeados 'selvagens' por ele - veneram o que eles próprios produziram, atribuindo a seus ídolos uma vida independente e o poder de governá-los por sua vez. Não se trata de uma ilusão ou enganação, mas do modo de funcionamento real da sociedade mercantil. Esta lógica da mercadoria domina todos os setores da vida, para muito além da economia (...) enquanto mercadorias, todos os objetos e todos os atos são iguais. Não passam de quantidades maiores ou menores de trabalho acumulado e, portanto de dinheiro. É o mercado que executa essa homologação,

\footnotetext{
${ }^{8}$ Intelectuais de pensamentos antagônicos comungam quanto ao iminente "perigo" pelo qual passa o sistema capitalista. $\mathrm{O}$ fundador e presidente executivo do Fórum Econômico Mundial, Schwab (2016, p.12), por exemplo, reconhece que "as mudanças são tão profundas que, na perspectiva humana, nunca houve um momento tão potencialmente promissor ou perigoso". Como representante incontestável dos interesses dos segmentos mais ricos das sociedades atuais ele aposta numa infinita capacidade de "adaptação" e "inventividade" dos indivíduos ao afirmar que: "os serem humanos possuem uma incrível capacidade de adaptação e inventividade. Mas o importante aqui é o tempo e o alcance em que o efeito capitalizador consegue suportar o efeito destruidor e a velocidade dessa substituição" (SCHWAB, 2016, p.42). Do outro lado do raciocínio concernente ao "perigo" e esgotamento das sociedades capitalistas, Kurz (1992), crítico anticapitalista, já declarou que o fim do capitalismo já se encontra em curso, como se refere o título de sua obra mais conhecida, "O colapso da modernização". Neste livro, o autor observa que "a "força produtiva ciência' gerada cegamente pelo próprio capitalismo criou assim um nível substancial-material potencias que já não são compatíveis com a forma básica da reprodução capitalista, configurando-se não obstante a encaixá-las forçosamente nessas formas. A consequência é a transformação das forças produtivas em potenciais destrutivos, que provocam catástrofes ecológicas e socioeconômicas" (KURZ, 1992, p.227). Para este pensador, o desafio consiste em superar a crise e o colapso do capitalismo por meio da emancipação social e não retroceder à lógica destrutiva do sistema. Pistas de como essa emancipação pode ocorrer pode ser verificado no site: http://obeco.planetaclix.pt/.
} 
para além das intenções subjetivas dos atores. O reinado da mercadoria é, portanto, terrivelmente monótono, e é até mesmo sem conteúdo uma forma vazia e abstrata, sempre a mesma, uma pura quantidade sem qualidade - o dinheiro - impõe-se pouco a pouco à multiplicidade infinita e concreta do mundo. (JAPPE, 2013, p. 234. Grifos do autor).

Nossa formação e desenvolvimento profissional, inclusive, não estão fora desta determinação histórica cultural real. Uma vez explicitado o contexto em que surgem os termos professoralidade, profissionalização, profissionalidade e profissionalismo, passamos a discutir estes conceitos e sua relação com o DPD.

\section{Professoralidade - entender para fazer no dia-a-dia docente}

Observamos, pela disponibilidade da produção acadêmica que tivemos acesso, alusivo aos quatro termos, que o de professoralidade é o menos debatido na literatura educacional.

A noção de professoralidade nos remete ao entendimento do professor como sujeito que se funda em sua práxis; ela diz respeito ao modo de pensar e agir do professor, que, ao assim fazê-los, vai se constituindo paulatinamente, sem que nunca se conclua. Para entender melhor esse conceito, buscamos apoio no raciocínio de Ferreira (2009) e na definição de Morosini et. al. (2006). Vejamos o que as duas pesquisadoras asseveram sobre o termo.

Para Ferreira (2009, p.8), professoralidade deve ser entendido em campo semântico mais amplo:

[...] entendo-a como a própria razão de ser da profissão, inserida no âmbito social, nas relações entre sujeitos, nas demandas cotidianas apresentadas. Por isto, a professoralidade não é ingênua e nem se produz ao acaso; reflete as condições, as relações sociais, a subjetividade e 
os poderes com os quais lidam os professores cotidianamente.

Já para Morosini (2006, p. 400), professoralidade é uma

Construção do sujeito-professor que acontece ao longo de sua vida; processo que o professor experimenta enquanto se pensa e se experimenta, produzindo um modo de ser singular. Em outras palavras, a professoralidade é uma marca produzida no sujeito, ela é um estado, uma diferença na organização da prática subjetiva, uma diferença que o sujeito produz em si. Vir a ser professor é vir a ser algo que não se vinha sendo, é diferir de si mesmo. E, no caso de ser uma diferença, não é a recorrência a um mesmo, a um modelo ou padrão. Por isso, a professoralidade não é uma identidade: ela é uma diferença produzida no sujeito. E, como diferença, não pode ser um estado estável a que chegaria o sujeito. A professoralidade é um estado em risco de desequilíbrio permanente. Se for um estado estável, estagnado, redundaria numa identidade e a identidade é uma determinação, uma redução das possibilidades de vir-a-ser a um padrão que tende a se repetir. (Grifo do autor).

Como argumenta Ferreira (2009), refletindo a partir de uma perspectiva ampliada, a professoralidade espelha as condições sociais recaídas sobre a categoria docente e, assim, ao fazê-lo, cada sujeito (professor) ecoa em sua particularidade estas condições, produzindo uma notória subjetividade. Por razão de ser da própria profissão, esta subjetividade agencia o conhecimento.

Morosini (2006), diferentemente de Ferreira (2009), parece não refletir de uma perspectiva tão ampla, mas também encara a professoralidade como uma "marca" única produzida no sujeito pela realidade. Isto é, a professoralidade é uma reação interna de algo vindo de fora, suscitando no sujeito professor algo provindo de si mesmo. Noutras palavras, não é algo vindo diretamente de fora, como que produzindo um 
reflexo, mas qualquer coisa que mobiliza o sujeito, internamente, e que por isso altera seu estado íntimo. Um estado novo da versão de si mesmo, despertado pela realidade, porém mais sujeito ao encaminhamento da subjetividade do que para a realidade externa. A realidade externa aqui, é encarada apenas como um gatilho ou disparador sobre a realidade interna ao sujeito, acabando por se completar e conjugar como um todo. Tudo o mais é obra das idiossincrasias do professor. Entretanto, o destaque do conceito de professoralidade, na perspectiva destes pesquisadores, parece ser a disposição e a produção permanente de singularidades que não se adéquam aos padrões de identidade, tornando-se um devir permanente e singular em cada professor.

Pelo que pudemos assimilar sobre professoralidade, o termo parece adequar-se ao pensamento de Bauman (2001) sobre as características das relações humanas, praxeomórfico na modernidade líquida. Segundo o sociólogo polonês, "o modo como os seres humanos entendem o mundo tende a ser sempre praxeomórfico: é sempre determinado pelo know-how do dia, pelo que as pessoas podem fazer e pelo modo como usualmente o fazem" (BAUMAN, 2001, p. 68, grifos do autor). Portanto, não somente entendem como também fazem. Deste modo, tudo depende dos recipientes disponíveis, isto é, das condições estruturantes imediatas dadas pela realidade e dos laços sociais daí advindos.

O conceito de professoralidade pode, por vezes, parecer confuso para algumas pessoas. Todavia, entendemos que a confusão daí advinda reflete muitas vezes da própria realidade em que ela surge. Uma realidade mutante em que os tradicionais padrões de valores, crenças e atitudes colidem com novas sensações gerando, assim instabilidades e crises individuais e sociais.

Compreendido o significado do termo professoralidade, a partir do exercício hermenêutico acima discutido, compreendemos que ela é resultante das condições mais recentes das duas últimas revoluções industriais. Este significado expressa, em nosso entendimento, o sentido que passaram a ter depois que a solidez e o peso das relações humanas deixaram de ser tão frequentes, pelo menos como existia no passado 
cedendo espaço à fluidez e à leveza de relações mais superficiais e de maior fluidez.

Portanto, embora a professoralidade não tenha passado remoto, pois pensamos tratar-se de fenômeno recente, não relacionado com o século da escola e do professorado, caracterizado no século XIX pela literatura educacional (LOPES, 2014), pode ser que tenha futuro, se considerarmos o pensamento de Santos (1989; 2002), uma vez que para este autor o paradigma científico emergente do "conhecimentoemancipação" pretende restaurar o equilíbrio entre os elementos objetivos e subjetivos da elaboração do conhecimento, de forma a equiparar suas condições de elaboração e o objeto do conhecimento. Caso a reflexão do sociólogo português vingue, no futuro, todo conhecimento (inclusive o científico como novo senso comum) transformar-se-á em autoconhecimento, então a professoralidade pode vir a ter presença garantida no futuro.

Sigamos agora a pensar na relação entre profissionalização e DPD.

\section{Profissionalização - uma autonomia que todos possam ver e sentir}

Profissionalização, diferentemente da professoralidade, que praticamente quase não comparece na urdidura da literatura educacional, é o termo mais exaltado em nossos dias, se comparado aos outros três termos discutidos neste trabalho. Segundo Nuñez e Ramalho (2008, p.4), ao tratarem da profissionalização docente, na atualidade, argumentam que ela é, "um movimento ideológico, na medida em que repousa em novas representações da educação e do ser do professor no interior do sistema educativo". Porém, trata-se de um movimento ideológico que se expressa mais (diga-se de passagem, muito mais) na produção científica dos pesquisadores educacionais e entre alguns técnicos dos órgãos do Poder Público, afinados com a pesquisa educacional, do que na existência de um movimento concreto do professorado, mormente do professorado da Educação Básica (RAMALHO; NUÑEZ; GAUTHIER, 2003). 
Reflexões sobre Professoralidade, Profissionalização, Profissionalidade, Profissionalismo e sua relação com o Desenvolvimento Profissional Docente

Uma definição interessante e aparentemente evidente de profissionalização docente foi concebida por Nóvoa, baseada no referencial de Mark Ginsburg, que considera a profissionalização "um processo através do qual os trabalhadores melhoram seus estatutos, elevam seus rendimentos e aumentam o seu poder de autonomia" (GINSBURG, 1990 citado por NÓVOA, 1995, p.23).

Ocorre que, no Brasil, inexiste um estatuto profissional unificado dos professores, ainda que o tema seja bastante debatido na pesquisa educacional (VEIGA; ARAÚJO; KAPUZINIAK, 2005). Muitos Estados da federação e vários municípios possuem seus próprios estatutos do magistério. É o caso, por exemplo, dos professores vinculados à Secretaria da Educação Básica do Estado do Ceará, regidos pelo Estatuto do Magistério Oficial do Estado, Lei n. 10.884, de 1984 (CEARÁ, 1984), e o dos professores vinculados à Secretaria Municipal da Educação de Fortaleza que são regidos, por sua vez, pelo Estatuto do Magistério do Município de Fortaleza, Lei n. 5.895, de 1984(PMF, 1984). Ambos, como podemos verificar, encontram-se defasados diante das mudanças da realidade e da legislação federal que regula a organização da Educação Básica no país.

Também verificamos não haver legislação no Brasil que estabeleça e assegure a autonomia docente ${ }^{9}$. Historicamente, a autonomia docente tem se caracterizado por avanços e retrocessos, de maneira incongruente, resultado de disputas entre professores de um lado, e governos e seus aliados conservadores da sociedade de outro. Exemplificando essa situação, Vicentini e Lugli (2009, p. 224) argumentam:

\footnotetext{
9 Podemos ler na Constituição Federal brasileira de 1988, no Artigo número 206, particularmente no item II, referência a "liberdade de aprender, ensinar, pesquisar e divulgar o pensamento, a arte e o saber" e no item III, referência ao "pluralismo de ideias e de concepções pedagógicas, e coexistência de instituições públicas e privadas de ensino". $\mathrm{Na}$ prática isso sempre foi contestada por várias instituições do Estado e da sociedade. Atualmente tramita no Congresso Nacional projeto denominado 'Escola sem partido' que contesta a letra da Constituição e tem o apoio dos segmentos mais conservadores da sociedade brasileira.
} 
Paradoxalmente, as demandas pela autonomia e aperfeiçoamento do magistério conviveram com iniciativas de padronização representadas por sistemas didáticos fechados, expostos de forma a serem seguidos em sala de aula. Escolas particulares e sistemas municipais de ensino têm adquirido certos conjuntos de livros impondo determinadas formas e ritmos de trabalho aos professores.

$\mathrm{O}$ vínculo dos profissionais docentes à estrutura do Estado certifica que seja de responsabilidade de órgãos como o Ministério da Educação e ou as respectivas Secretarias da Educação de Estados/Distrito Federal e, ainda, de municípios que legislam unilateralmente sobre a formação e o direito de atuação no sistema educacional ${ }^{10}$.

No Brasil, observamos que os professores da Educação Básica parecem viver a autonomia profissional mais oficiosamente que oficialmente, pois enquanto os governos aprovam as leis que lhes convêm e à revelia da participação e posicionamento dos profissionais do ensino, estes, por sua vez, as interpretam e as executam conforme suas conveniências e situações, adaptando-as assim às condições em que se encontram. A vivida autonomia docente é consecutivamente "relativa", porque depende mais das pressões sociopolíticas momentâneas locais dos grupos políticos organizados no poder executivo do que propriamente do emprego da legislação. Professores, sistemas de ensino e governos fazem parte dela, considerando também o que já foi dito sobre os constrangimentos mais amplo impostos pela lógica subjacente ao fetichismo da mercadoria.

Deslocando a discussão conceitual da autonomia como percurso da profissionalização docente para a dimensão histórica da profissionalização, deparamo-nos com o trabalho realizado por Lopes (2014). Esta pesquisadora efetuou um estudo comparativo sobre o que diziam as

${ }^{10}$ Conforme deixou claro a 'Nota' assinada por cinco entidades nacionais (ANPED, ANFOPE, ANPAE, CEDES e FORUMDIM) da área da Educação, ao se posicionaram contrária a regulamentação do exercício da profissão de Pedagogo, conforme os termos do Projeto de Lei n. 6.847/2017 (ANPED, 2017). 
publicações pedagógicas do Rio de Janeiro e Lisboa, acerca da melhoria do estatuto profissional docente na segunda metade do século XIX. Concluiu que

[...] ao final de Oitocentos, iniciou-se um processo de afirmação do estatuto profissional docente. Em parte, o prestígio foi alavancado pela exigência de uma formação especializada no âmbito das escolas normais, nas quais se esperava que os alunos obtivessem o domínio das ciências da educação, em parte pela recusa de um modelo profissional que se assentava no paradigma do sacerdócio e que acabou por abrir espaço às associações sindicais. (LOPES, 2014, p.97, grifos da autora).

Trocando, na citação acima, a expressão escolas normais por Instituições de Ensino Superior (IES), cabe questionar: que mais diferencia o final do século XIX do início do século XXI? No fundo, as reivindicações docentes parecem ser sempre as mesmas, o que muda é o contexto. Às vezes, e após intensas lutas ${ }^{11}$ docentes por ampliação da chamada relativa autonomia ${ }^{12}$ profissional, remuneração salarial condizente com a complexidade do ensino e melhores condições de trabalho, tendo em vista um processo de afirmação do estatuto profissional, como no século XIX, damo-nos conta de que os professores repetem o que gerações docentes anteriores já fizeram, não conseguindo as melhorias almejadas, ou, se as conseguiram, logo em seguida estas foram revogadas em uma só canetada, por uma autoridade ${ }^{13}$ de escalão maior do poder.

11 Sobre as lutas dos professores da Educação Básica por melhorias no seu estatuto profissional ver, por exemplo: Vicentini e Lugli (2009) e Pessanha (2001).

${ }^{12}$ É interessante observar que o fim da autonomia do professor ocorreu com a primeira constituição republicana brasileira, ocorrido em 1891, quando o ensino primário passou a fazer parte da responsabilidade do Estado. Sobre isso Veiga; Araujo; Kapuziniak (2005, p. 20) argumentaram: "o Estado se aproveita do trabalho do mestre-escola, transformando-o em funcionário público. Em troca do salário, o Estado normatiza o trabalho de ensinar, tirando-lhe a antiga autonomia"

${ }^{13}$ Foi o que fez o governo Temer, quando, por exemplo, revogou a obrigatoriedade do ensino de quase todas as disciplinas do Ensino Médio, com exceção de Língua Portuguesa, Língua Inglesa e Matemática, e abriu as salas de aula para a substituição de professores 
Em tese, o entendimento de autonomia, é a expressão da prática autorregulada, o conceito-chave que, vivenciado, pode diferenciar as categorias profissionais entre aquelas que, mais ou menos, ou, ainda, não controlam os próprios processos, valores e pretensões profissionais. De acordo com Nóvoa (1995), de quem se fez referência acima, a profissionalização docente deve se harmonizar progressivamente com a autonomia profissional.

Contreras (2012) tem se afirmado como um destacado pesquisador quando o tema é a autonomia de professores. Este autor asseverou na primeira parte de sua obra, que a ideia de autonomia docente deve ser pensada a partir de três modelos teóricos para a categoria de professor: a do especialista técnico, a do profissional reflexivo e a do professor como intelectual crítico.

Para Contreras (2012, p.211), na concepção do especialista técnico, a autonomia é "como status ou como atributo. Autoridade unilateral do especialista. Não ingerência. Autonomia ilusória: dependência de diretrizes técnicas, insensibilidade para com os dilemas, incapacidade de resposta criativa diante das incertezas". No modelo do profissional reflexivo, autonomia é identificada "como responsabilidade moral e individual, considerando os diferentes pontos de vista. Equilíbrio entre a independência do juízo e a responsabilidade social. Capacidade de resolver criativamente as situações-problema para realização prática das pretensões educativas". Por último, para o intelectual crítico, o autor afirma que a autonomia é caracterizada "como emancipação: liberação profissional e social das opressões. Superação das distorções ideológicas. Consciência crítica. Autonomia como processo coletivo (configuração discursiva de uma vontade comum), dirigido à transformação das condições institucionais e sociais de ensino". Certamente que, como esse entendimento de autonomia, a relação entre profissionalização e DPD parece ocorrer de forma espontânea, isto é, sem a percepção dos

licenciados pela presença de pessoal portador de notáveis saberes na Educação Básica, conforme a Lei n. 13.415, de 16 de fevereiro de 2017. (BRASIL/CASA CIVIL DA PRESIDÊNCIA, 2017). 
constrangimentos infligidos pela sociedade mercantil, que nem de longe o autor faz alusão.

Todavia, apesar dos modelos a que faz referência, Contreras (2012, p. 210) argumenta que, no contexto da prática do ensino, a autonomia "deve ser entendida como um processo de construção permanente ao qual devem se conjugar, se equilibrar e fazer sentido, muitos elementos. Por isso, pode ser descrita e justificada, mas não reduzida a uma definição autoexplicativa". Vemos, nesta afirmação, investida no intuito de justificar uma posição mais crítica, uma vez que ao final da sua argumentação, ele segue o modelo baseado na reflexividade. No Brasil, a autonomia docente parece ser vivida pelo que é possível realizar na escola, conforme as condições e pressões sociopolíticas do momento vivenciado. Deste modo, a autonomia é sempre relativa a alguma coisa e a algum momento.

A profissionalização docente, no contexto em que nos encontramos, parece ter-se convertido numa ideologia que torna o professorado mais uma categoria liberal do mercado, devendo apresentar resultados imediatos, a exemplo do engenheiro civil, que estabelece seu salário pela quantidade de obras que acompanha e finaliza, e não um profissional que, ao interagir por meios simbólicos com os educandos, medeia suas formações e colabora com a construção, em longo prazo, da cultura letrada. Ramalho, Nuñez e Gauthier (2003, p.63) advertem:

A profissionalização é parte do movimento global de "terceirização" das sociedades desenvolvidas e do aumento contínuo das forças de trabalho, especialmente nas áreas de assistência básica às pessoas (saúde física e mental, trabalho social, informação, lazer e educação). Quando o progresso tecnológico garante um aumento de produção de bens de consumo, com cada vez menos postos de trabalho no setor agrícola e industrial, torna-se evidente que a multiplicação, a diversificação, a sofisticação e a estratificação dos postos de trabalho do setor terciário é a única alternativa ao desemprego em massa. Um pouco cinicamente, podemos então dizer que a 
profissionalização do setor terciário não procura responder às necessidades dos usuários, mas sim às táticas de melhoria ou de consolidação do estatuto dos seus próprios profissionais.

Parece que nem por meios "cínicos"14, como apontam os autores, o estatuto dos docentes tem melhorado. O discurso da profissionalização incute no imaginário docente aproximações às características dos chamados profissionais liberais, que agem segundo seus interesses e não movido pelos interesses sociais. Denota um limitado desempenho técnico e não um desempenho sensível das necessidades humanas, bem como uma dinâmica que reforça os valores da atual sociedade e não uma dinâmica que conteste o sucesso quando tudo ao seu redor reflete o desemprego em massa. Assim, a profissionalização como ideologia, relaciona-se à massificação do ensino e ao movimento de proletarização em curso que abrange várias categorias profissionais (CONTRERAS, 2012).

No plano da "elevação dos rendimentos", conforme publicação da APEOC (2012) pertinente a carreira de professores de 10 (dez) Estados da federação, das regiões Norte e Nordeste, os rendimentos se encontram atrelados às negociações que os sindicatos da categoria realizam com os governos. Nestas negociações, geralmente a ascensão na carreira ocorre por meio de dois modelos de progressão: horizontal e a vertical.

No Ceará, conforme ainda a APEOC (2012, p.26), para os professores vinculados à rede pública estadual, a progressão horizontal ocorre quando da "passagem de um servidor de uma mesma classe ${ }^{15}$ para as referências seguintes daquela classe". Por exemplo, a classe dos professores especialistas enfrenta várias referências a serem galgadas, até que cheguem ao topo desta classe e tenham sua remuneração estacionada

\footnotetext{
${ }^{14}$ Esta expressão, usada no sentido moderno e vulgar pelos autores, parece querer dizer algo como um comportamento pessoal que pode prejudicar outros de alguma forma, mas mesmo sabendo disso, o fazem. Diferentemente da filosofia cínica, do período helênico antigo, em que o seu sentido dizia sobre a busca de uma vida de virtude moral em que os excessos, sobretudo materiais e exteriores ao espírito honesto, eram afastados tendo como referência uma vida errante e instintiva

${ }^{15}$ As classes a que se refere à APEOC (2012, p. 25) dizem respeito aos níveis de formação, isto é, médio, graduado, especialista, mestre e doutor.
} 
Reflexões sobre Professoralidade, Profissionalização, Profissionalidade, Profissionalismo e sua relação com o Desenvolvimento Profissional Docente

na carreira. $\mathrm{Ou}$, no caso do professor que quiser ascender no rendimento, ele tem que realizar curso de mestrado e depois um doutorado, para, deste modo, ascenda na chamada progressão vertical, que também tem um topo para estacionar ${ }^{16}$ (APEOC, 2012). Assim sendo, a progressão vertical é "a passagem de um servidor de uma classe para outra".

Portanto, no esquema da progressão horizontal não há necessariamente espaço para o desenvolvimento profissional do professor, pois as progressões na "carreira" dizem respeito apenas ao tempo de serviço do professor no magistério. Quanto à progressão vertical, o professor pode realizar um curso de pós-graduação stricto sensu, mas em alguns casos este pode não ter relação direta com a sua área de atuação profissional, o que pode gerar processos administrativos para a obtenção dos ganhos nos rendimentos. Uma vez transposta esta questão, realiza-se a progressão vertical.

Deste modo, a profissionalização docente não pode ser entendida, necessariamente, como é reivindicada APEOC (2012), quando somente almeja o aperfeiçoamento do estatuto e o aumento do rendimento dos professores, sem, no entanto, contribuir para o aumento de seu poder de autonomia ${ }^{17}$.

Sendo assim, a profissionalização docente tem se caracterizado, de fato, como um movimento ideológico. Uma vez compreendida como ideologia, a linha de pensamento desenvolvida por Karl Marx, isto é, a

\footnotetext{
${ }^{16}$ Conforme Tabela de vencimentos do grupo ocupacional do magistério da Educação Básica do estado do Ceará, do ano 2016, o professor doutor com carga horário de 40h. tem o vencimento de até $\mathrm{R} \$$ 8.614,47. Disponível em: https://www.apeoc.org.br/wpcontent/uploads/2016/11/Tabela-40h-2016.pdf. Acesso em: 26 jan. 2017. Diferentemente do que acontece com funcionários federais da área judiciária, em que, por exemplo, sem respeitar limites constitucionais, desembargadores chegam a vencimentos de até mais de 100 mil reais. Mais detalhes sobre o assunto ver a matéria "Desembargadores de todo o país têm supersalários". Disponível em: http://congressoemfoco.uol.com.br/noticias/maioriados-desembargadores-recebe-supersalarios/. Acesso em: 26 jan. 2017.

${ }^{17}$ Em Portugal, onde este desenho parece funcionar, por exemplo, "a progressão fazia-se e faz-se em função do tempo de serviço prestado e da avaliação de toda a actividade desenvolvida, bem como das qualificações profissionais, pedagógicas e científicas" (ESTEVES et. al., 2012, p.8).
} 
dedução do real a partir das ideias do real, ou seja, o mascaramento da realidade social ao se tomar o falso por verdadeiro e esclarecido.

Em acréscimo, se relacionarmos profissionalização à autonomia dos professores no âmbito escolar, como proposto à letra da Constituição brasileira ao fazer referência às liberdades de gestão e pluralismo de ideias e concepções pedagógicas, observamos na atualidade um movimento contrário ao previsto neste marco legal, pois nunca se verificou tantas ofensivas à profissionalização dos docentes, desde a abertura política iniciada nos anos 1980. Exemplo disto reside na noção de que inserir na educação profissionais com "notório saber" é mais vantajoso do que desenvolver nos docentes as competências necessárias para o exercício da sal profissão. Também, se se concretizar as propostas divulgadas na imprensa do eleito presidente do Brasil, Jair Bolsonaro, a educação escolar desde o Ensino Fundamental passará a ser realizada a distância e, consequentemente, os professores deixaram de cumprir o papel de formadores para se restringirem ao papel de tutores ${ }^{18}$.

Relacionando o tema profissionalização com o DPD, podemos inferir a partir do que foi visto até aqui, que longe de ser uma relação espontânea de colaboração e complementariedade mútua, como ocorre com a categoria professoralidade, é uma relação problemática em que os dois processos podem ocorrer desvinculados um do outro. Os professores da Educação Básica desconhecem na prática o que venha a ser profissionalização de sua categoria profissional ainda que muitos trabalhos acadêmicos ressaltem essa perspectiva como ideologia. Ao mesmo tempo, talvez em decorrência dessa ideologia alardeada nas produções acadêmicas que muitos professores têm acesso, muitos docentes passaram a enxergar o DPD como um valor a ser conquistado por meio da realização de sua

\footnotetext{
${ }^{18}$ Mattar (2012, p. xxiv) alerta que "a atividade de tutoria é encarada por muitos de maneira pejorativa, como rebaixamento da função docente". O tutor desenvolve atividade de organização da classe virtual, se responsabiliza em gerar senso de comunidade entre os discentes e conduzir os processos pedagógicos e tecnológicos virtuais (MATTAR, 2012). "Na prática, ele [o tutor] encontra naturalmente dificuldades para cumpri todas essas funções" (MATTAR, 2012, p.xxvi). Ainda não temos notícias de tutores trabalhando na Educação Básica, mas apenas no Ensino Superior.
} 
formação continuada em curso de pós-graduação (lato sensu e stricto sendo, acadêmica e profissionalizante) e por outros meios, ${ }^{19}$ de modo a ampliar melhorias temporárias ${ }^{20}$ na remuneração e, ao mais importante, na compreensão e domínio dos processos teóricos e técnicos educacionais com os discentes na sala de aula.

Nuñez e Ramalho (2008), por sua vez, pensam a profissionalização docente como sendo constituída por dois aspectos ou dimensões intercaladas, isto é, algo transpassado simultaneamente pelo profissionalismo e a profissionalidade. Para os autores, enquanto a segunda dimensão é apresentada como interna aos processos de profissionalização, a primeira se apresenta como externa, mas mesmo assim, conforme estes autores, essas categorias não devem ser tratadas separadamente.

Seguindo a conceituação dos termos pensados por Nuñez e Ramalho (2008), vamos abordá-los separadamente, tendo em vista que nosso objetivo, neste momento, é realizar uma análise acurada e refletir estes termos em relação ao DPD.

\section{Profissionalismo - ética e poder numa visão compartilhada de mundo}

Profissionalismo é um termo abundantemente empregado na linguagem técnica de várias profissões e não somente no que concerne aos profissionais docentes. Ele contrapõe-se às atitudes amadoristas de trabalhadores no mercado de trabalho. Talvez até aqui ele seja mais empregado em outros campos de atuação do que propriamente na Educação, ainda que para o futuro os portadores de "notórios saberes" devam se tornar mais presentes nas escolas de Educação Básica, como presume a reforma do Ensino Médio (BRASIL, 2017). Provavelmente, a inclusão destas destes profissionais com notórios saberes, deva ocorrer não por pessoas desinteressadas em uma educação escolar libertadora dos

\footnotetext{
${ }^{19}$ Por exemplo, participando como bolsista de programas educacionais como o PIBID (ROCHA, 2018).

${ }^{20}$ Vivemos numa época em que as conquistas trabalhistas passaram a serem flexíveis e várias reformas políticas garantam a intermitência do trabalho, inclusive a de docentes.
} 
interesses do mercado, principalmente, mas por 'sábios' de igrejas com sua teoria criacionista e favoráveis a ideologia da tradição familiar e por empreendedores interessados em mão-de-obra admoestada para ocupar postos de trabalhos temporários e flexíveis.

Mesmo vivendo na "crise do profissionalismo" (TARDIF, 2010, p.252) ${ }^{21}$, há quem acredite no seu "renascimento" (FREIDSON, 1998), o que nos parece uma crença acertada, haja vista que o mercado de trabalho se retorce em transformações, fazendo desaparecer ocupações e surgir outras novas, com períodos de renovação cada vez mais frequentes. Relacionado ao tema do profissionalismo Schwab (2016, p. 43) prevê que com a quarta revolução tecnológica,

[...] poderá dar origem a um mercado de trabalho cada vez mais segregado em segmentos de baixa competência/baixo salário e alta competência/alto salário, ou conforme previsto por Martin Ford, autor e empresário de software do vale do silício, a menos que nos preparemos hoje para as alterações, o esvaziamento de toda a base da pirâmide de habilidades profissional levará a uma crescente desigualdade e ao aumento das tensões profissionais.

Tais manifestações são indicadores de crise, ainda mais segregadora, e, contraditoriamente, podem ser de renascimento também numa nova forma de profissionalismo. Assim, justifica-se o brado por profissionalismo em áreas de trabalho ainda quase sem cultura ocupacional reconhecida.

Por outro lado, começa a surgir no horizonte uma "revolta contra o profissionalismo" (CARLSSON, 2014, p.48) do chamado mundo do trabalho. Carlsson (2014) observa esta realidade a partir dos Estados Unidos. Ele argumenta que o profissionalismo está vinculado à cultura das

${ }^{21}$ Crise do profissionalismo diz respeito, conforme Tardif (2010, p.252) "a crise da ética profissional, isto é, dos valores que deveriam guiar os profissionais". 
classes médias e que ela traz uma ideia de controle sobre as palavras e comportamentos das pessoas no ambiente laboral. Que profissionalismo geralmente demanda um certificado de curso de nível superior e que, por isso, tem a ver com formação profissional e, por conseguinte, com exclusão daqueles que não se encaixam na "cultura de elite autoperpetuante" (CARLSSON, 2014, p.49). Argumenta, ainda, que ocorre um crescente descontentamento e desistência à expertise devido à falta de sentido de uma vida perdida para direções de empresas e órgãos públicos, sobretudos universidades. E arremata uma crítica ao profissionalismo dizendo que:

A rejeição ao profissionalismo anda de mãos dadas com o surgimento de comunidades de base do tipo "faça você mesmo", muitas vezes sustentadas pela atividade de ex-profissionais ou de gente que poderia ter sido profissional, que se afastou em busca de uma vida mais gratificante. A corrida de ratos recebeu seu nome apropriados a décadas - é uma vida enlouquecida, vazia e integralmente sacrificada. Muitas pessoas saem voluntariamente para recuperar sua dignidade humana básica. Enquanto isso, a pressão aumenta a partir de baixo. As agendas capitalistas enfrentam oposição cada vez mais sofisticada, as vezes, impulsionada por antigos profissionais participantes que se rebelam. Os movimentos de base enfrentam cada vez mais os chamados especialistas que tomam decisões em bases supostamente técnicas, as quais são, na verdade, profundamente sociais (CARLSSON, 2014, p.52).

Voltando à realidade brasileira e à especificidade do profissionalismo na docência, Nuñez e Ramalho (2008, p. 4) dizem que o termo se refere à

Expressão da dimensão ética dos valores e normas, das relações, no grupo profissional, com outros grupos. É mais do que um tema de qualificação e 
competência, uma questão de poder: autonomia, face à sociedade, ao poder político, à comunidade e aos empregadores; jurisdição, face aos outros grupos profissionais: poder e autoridade, face ao público e às outras profissões ou grupos ocupacionais.

Do excerto acima, vemos o destaque dado às dimensões da ética e do poder. Confrontando esse entendimento de profissionalismo com os de outros pesquisadores educacionais, podemos observar algumas distinções. Por exemplo, para Libâneo (2011, p.90), profissionalismo significa "compromisso como projeto político democrático, participação na construção coletiva do projeto pedagógico, dedicação ao trabalho de ensinar a todos, domínio da matéria e dos métodos de ensino, respeito à cultura dos alunos, assiduidade, preparação de aulas etc.". Neste entendimento de profissionalismo as dimensões cardinais destacadas, ainda que com outros nomes, parecem apontar para o mesmo sentido, todavia com menos ênfase no poder e mais reforço na obrigação para com o alunado.

Contreras (2012, p.68), ao elaborar seu estudo sobre a autonomia de professores, dividiu-o em três seções, de forma a dedicar a primeira ao tema do profissionalismo no ensino. Com relação a esta parte, o autor trata do processo de proletarização, do controle do ensino pela técnica, da retórica e suas ambiguidades, da ideologia subjacente do profissionalismo e de seus valores. Faz referência a dois pesquisadores com quem parece concordar, para esclarecer o que ele entende por profissionalismo. Segundo Lawn e Ozga, citados por Contreras (2012, p.46),

Entre os professores, o profissionalismo pode ser considerado uma expressão do serviço à comunidade, bem como em outros tipos de trabalho [...]. Também se pode considerar uma força criada externamente que os une numa visão particular de seu trabalho [...]. O profissionalismo é, em parte, uma tentativa social de construir uma "qualificação"; a autonomia era, em parte, a criação por parte dos professores de um espaço defensivo em torno da referida "qualificação". 
Reflexões sobre Professoralidade, Profissionalização, Profissionalidade, Profissionalismo e sua relação com o Desenvolvimento Profissional Docente

Em nosso entendimento, essa compreensão de profissionalismo se assemelha bastante a de Libâneo (2011) e não acrescenta muito ao que este já formulara, a não ser pela ideia de "uma força criada externamente" e que parece se referir à demanda social pelo ensino.

A partir dos autores acima sobre profissionalismo, inferimos que o vocábulo "compromisso", manifesto por Libâneo (2011), é um termo forte para designar a obrigação do professorado com o fazer-se docente. Compromisso este, a nosso ver, que não deve se limitar aos formalismos da lei e que repercute na carga horária do professor atribuída pela escola, ainda mais se considerarmos a rapidez com que as demandas e exigências têm sido feitas à escola e ao professorado. Nele, também, impõe-se a dimensão ética dos valores apontados por Nuñez e Ramalho (2008).

Em síntese, entendemos o profissionalismo docente como sendo o compromisso do professorado para com o projeto pedagógico autônomo, resultado do debate da comunidade escolar e que transpõe o limite da sala de aula, associado aos valores éticos e emancipatórios. Todavia, como já fizemos referencia acima, cada vez mais os professores parecem perder espaço para segmentos conservadores organizados politicamente no Congresso Nacional, que questionam a autonomia docente frente às demandas do conteúdo do currículo e gestão na sala de aula.

Relacionar este estado de coisas que chamamos profissionalismo docente com DPD pode nos posicionar diante de três perspectivas muito diferentes. Uma perspectiva é a de integração maior ao establishment, isto é, às regras e normas sociais e escolares estabelecidas. Uma vez que atualmente segmentos organizados, que justamente por reconhecerem o papel da educação escolar como espaço de desenvolvimento de conhecimentos, habilidades e atitudes capazes de liberar comportamentos obsoletos, pretendem retroceder as conquistas ${ }^{22} \mathrm{e}$, assim, impor uma

\footnotetext{
22 As conquista se refere ao que diz o texto da constituição Federal brasileira de 1988, particularmente referentes ao artigo 206 que trata dos princípios referentes à igualdade de condições, liberdades de ensinar e aprender, pluralismo das ideias, entre outras. Uma conquista mais recente e importante a que nos referimos refere-se à Lei do Piso Nacional do Magistério (Lei n. 11.738 de 2008) que estabelece 2/3 do tempo do trabalho docente em
} 
ideologia conservadora para salvaguardar seus valores e crenças sobre o conjunto da sociedade. Esta posição dificilmente empodera a ação do professor e, portanto, não colabora para o seu DPD, quando muito, pelo contrário, enlaça suas iniciativas puxando para período anterior da Lei de Diretrizes e Bases da Educação Nacional (Lei n. 9.394/96).

Outra perspectiva referente ao profissionalismo docente relacionada com o DPD pode mostrar-se menos conservadora, mas não menos mantedora do desmonte anunciado. Esta perspectiva aposta em reformas educacionais liberais e processuais como meio de controle sobre o professorado e o seu DPD ao estilo 'conta gotas', por assim dizer. Pensamos que esta perspectiva considera também o jogo político no tocante a racionalidade dos custos e benefícios econômicos e ao poder de mobilização da categoria profissional dos professores em suas lutas. Em todo caso, é bom ressaltar que a qualquer sinal de amplo descontentamento social esta perspectiva pode retroceder para não perder a aderência da maioria dos atores sociais ou pelo menos diminuir os efeitos das conquistas alcançadas fazendo com que a lei não prevaleça na prática. Nesta perspectiva, a relação entre profissionalismo e DPD ocorre mais como retórica e menos como algo concreto. Acena para o profissionalismo e o DPD, mas sem compensações palpáveis, por exemplo, melhores remunerações e reconhecimento das ações docentes desenvolvidas para a contagem de tempo para a aposentadoria, mas por meio de bolsa de programas temporária. Efetivamente, essa perspectiva não leva ao profissionalismo e ao DPD em toda sua consequência, mas apenas faz de conta que faz.

Uma terceira perspectiva se associa à rejeição do profissionalismo à maneira que Carlsson (2014) aborda o tema. Isto, contudo, não significa abandono das ações motivadas pela ética, pelo compromisso com o aprimoramento dos processos de ensino e aprendizado, por meio de uma vinculação favorável e emancipatória entre docentes e discentes na escola, conforme a maneira abordada por Libâneo (2011) e Contreras (2012).

atividades de interação com os educandos de forma a dedicar 1/3 para atividades para planejamento e formação. 
Reflexões sobre Professoralidade, Profissionalização, Profissionalidade, Profissionalismo e sua relação com o Desenvolvimento Profissional Docente

Como argumentamos antes juntamente Carlsson (2014), o problema passou a ser da própria estrutura das empresas e repartições estatais, que enrijeceram e passaram a pressionar por uma adaptação cega e incondicional aos constrangimentos institucionais das regras do mercado e suas inovações absurdas, sem reconhecer a crise do profissionalismo como percebida por Tardif (2010). Esta perspectiva adaptativa não valoriza as iniciativas concretas do bem viver em comunidade baseada na ética e compromisso (LIBÂNEO, 2011; CONTRERAS, 2012) de uns com outros, sem cair na cilada da adoção de códigos de profissionalismo abstratos e que desconhecem a realidade das contradições de uma sociedade subjugada pelo fetichismo da mercadoria. Nesta perspectiva, se o DPD ocorrer, será mais como consequência das várias ações espontâneas e conscientes de seus adeptos, do que de uma adaptação irrestrita aos valores do profissionalismo em crise.

Prosseguimos, agora, com a discussão do último dos quatro termos que analisamos em relação ao DPD: a profissionalidade.

\section{Profissionalidade - o que faz o professor ser professor}

Passemos a refletir, conforme pensam Nuñez e Ramalho (2008), sobre a dimensão interna da profissionalização docente: a profissionalidade. Diferentemente da dimensão externa da profissionalização, isto é, do profissionalismo, a profissionalidade cumpre um papel que Sacristán (1991, p.64) assinala como sendo aquilo que é afirmativo e específico da ação docente, isto é, "o conjunto de comportamentos, conhecimentos, destrezas, atitudes e valores que constituem a especificidade de ser professor". Assim caracterizada, a profissionalidade apresenta-se como a dimensão antropológica do professorado, ou seja, do que faz com que um professor seja o que vem sendo.

Nos dias atuais, o termo profissionalidade está, em grande parte, relacionado à "hiper-responsabilização" (SACRISTÁN, 1991, p. 63), que o discurso pedagógico dos segmentos dominantes da sociedade confere aos 
docentes, ao acusá-los pelos baixos índices de aprendizagem discente e a má qualidade do ensino. Esta situação reflete o papel institucional central que o sistema de ensino unilateralmente atribui aos docentes, pelo sucesso ou insucesso da educação escolar, de modo a tentar infligir um modelo de ser profissional aos professores (SACRISTÁN, 1991).

Paralelamente à esta crítica, que segmentos dominantes atribuem aos professores, outra fração da sociedade, particularmente associada a determinados grupos religiosos, forma no Congresso Nacional brasileiro, uma bancada evangélica para fazer valer suas crenças e interesses doutrinários e econômicos no campo educacional. Um destes interesses diz respeito ao Programa Escola Sem Partido (Projeto de Lei - PL n. 867/2015), ação de iniciativa do deputado Izalci Lucas $^{23}$, da referida bancada.

Em nosso entendimento, o Programa 'Escola Sem Partido' encontra-se em flagrante descompasso com o que prevê a Resolução n. 2, de $1^{\circ}$ de julho de 2015, do MEC e do Conselho Nacional de Educação (CNE), que definiu as Diretrizes Curriculares Nacionais para a formação inicial em nível superior (cursos de licenciatura, cursos de formação pedagógica para graduados e cursos de segunda licenciatura) e para a formação continuada dos professores e com a própria Constituição Federal (BRASIL, 1988), particularmente com o artigo 206, já abordado anteriormente neste trabalho. Este descompasso se revela ao não se respeitar os princípios dos direitos humanos que fundamentam a formação e as práticas pedagógicas que despontam da citada Resolução. As Diretrizes (BRASIL/MEC/CNE/CP, 2015, p.2) consideram que

\footnotetext{
${ }^{23}$ Entre as ações importantes deste deputado federal do Partido da Social Democracia Brasileira (PSDB) do Distrito Federal (DF), destaca-se sua participação na presidência da comissão especial na Câmara dos Deputados que encaminhou a Medida Provisória da Reforma do Ensino Médio que se tornou a Lei n. 13.415/2017. Votou a favor da aprovação da Proposta de Emenda constitucional (PEC) n. 241 que congelou os investimentos públicos na área social, incluindo a da educação, por um período de 20 anos e também votou a favor da permanência de Michel Temer na Presidência da República quando foi acusado pelo Ministério Público Federal de prática de corrupção.
} 
[...] a educação em e para os direitos humanos é um direito fundamental constituindo uma parte do direito à educação e, também, uma mediação para efetivar o conjunto dos direitos humanos reconhecidos pelo Estado brasileiro em seu ordenamento jurídico e pelos países que lutam pelo fortalecimento da democracia, e que a educação em direitos humanos é uma necessidade estratégica na formação dos profissionais do magistério e na ação educativa em consonância com as Diretrizes Nacionais para a Educação em Direitos Humanos.

Por sua vez, no campo jurídico, o Ministério Público Federal/Procuradoria Federal dos Direitos do Cidadão (MPF/PFDC) manifestou, em 21 de julho de 2016, por meio da Nota Técnica n. 01/2016, a "inconstitucionalidade" do PL n. 867/2015, que propõe instituir o Programa ‘Escola Sem Partido' na Educação. Para o MPF/PFDC (2016), o referido PL:

subverte a atual ordem constitucional, por inúmeras razões: (i) confunde a educação escolar com aquela que é fornecida pelos pais, e, com isso, os espaços público e privado; (ii) impede o pluralismo de ideias e de concepções pedagógicas (art. 206, III); (iii) nega a liberdade de cátedra e a possibilidade ampla de aprendizagem (art. 206, II); (iv) contraria o princípio da laicidade do Estado, porque permite, no âmbito da escola, espaço público na concepção constitucional, a prevalência de visões morais/religiosas particulares.

Embora importante, a Nota do MPF//PFDC não tem força de Lei e não impede o andamento e, talvez, a aprovação desta proposta em âmbito estadual e municipal, enquanto não for votada e vetada no Congresso Nacional. Somente através de mobilização ampla e mediante adesão popular contrária poder-se-ia barrar a pretensão dos segmentos mais conservadores da sociedade no tocante à imposição de seus valores ao conjunto da coletividade. 
O ordenamento do referido PL incide, ainda, na discussão sobre o conceito de profissionalidade, pois segundo Nuñez e Ramalho (2008, p. 4), este termo expressa

[...] a dimensão relativa ao conhecimento, aos saberes, técnicas e competências necessárias à atividade profissional. Por meio da profissionalidade, o professor adquire as competências necessárias para o desempenho de suas atividades docentes e os saberes próprios de sua profissão. Ela está ligada às seguintes categorias: saberes, competências, pesquisa, reflexão, crítica epistemológica, aperfeiçoamento, capacitação, inovação, criatividade, pesquisa, dentre outras, componentes dos processos de apropriação da base da docência como profissão.

Esta compreensão da profissionalidade está em consonância com o que Sacristán (1991) elaborou e a que já fizemos referência acima e, também, com o que Contreras $(2012$, p.82) pensa, ao se referir à profissionalidade como sendo "as qualidades da prática profissional dos professores em função do que requer o trabalho educativo". Também é condizente com a elaboração de Brzezinski (2002, p.10), que conceitua ser profissionalidade "o conjunto maior ou menor de saberes e de capacidades de que dispõe o professor, no desempenho de suas atividades, e o conjunto do grupo profissional dos professores num dado momento histórico".

Assim sendo, partindo desses autores, entendemos profissionalidade como o conjunto de saberes, conhecimentos, habilidades e competências elaboradas e organizadas pelo professorado para a realização do seu trabalho pedagógico, que ocorre num espaço concreto e em determinado tempo. Tempo este em que as funções docentes são consideradas em parte do imaginário coletivo como bico $^{24}$; em que a

${ }^{24}$ Alves e Pinto (2011, p. 621), baseados em micro dados da Pesquisa Nacional de Domicílio e do Censo Escolar (PNAD) advertem que "4,2\%" dos professores da Educação Básica têm o ensino como "bico". Silva (2013, p. 109), por sua vez, argumentou que "uma pesquisa realizada pelo IBGE, em 2006, revelou que 7,2\% dos professores brasileiros ainda têm a docência como 'um bico"'. Uma discussão mais conceitual sobre o 'bico' no sistema de ensino escolar pode ser visto em Haguette (1990). A prática do "bico" ganhou reforço com a recente Lei n. 13.415/2017, que prevê a presença de portadores de "notável saber" na 
Reflexões sobre Professoralidade, Profissionalização, Profissionalidade, Profissionalismo e sua relação com o Desenvolvimento Profissional Docente

autonomia profissional se caracteriza, aos nossos olhos, similar àquela do século XIX (LOPES, 2014); em que a profissionalização não é mais do que um movimento meramente ideológico (NUÑEZ; RAMALHO, 2008).

Ao relacionar profissionalidade com DPD, inferimos que se trata de uma relação intrínseca, uma vez que não é possível desenvolvimento profissional sem que conhecimentos, atitudes e habilidades sejam mobilizadas nos professores. Dos quatro termos analisados nesta reflexão, profissionalidade e professoralidade sejam aqueles que mais dizem respeito a uma estreita vinculação com o desenvolvimento profissional.

Todavia, diferentemente da professoralidade, profissionalidade depende mais das condições externa a personalidade do docente do que a outra categoria para o seu aprimoramento, ainda que profissionalidade digam mais a questões interna do desenvolvimento docente. Por isso é tão importante que professores estejam atentos às políticas públicas que lhes afetam diretamente como o Programa 'Escola Sem Partido' em tramitação no Congresso Nacional no momento que escrevemos e que empregamos para exemplificar a situação desta categoria com a realidade política e social mais ampla que nos encontramos.

Nosso entendimento é que não é possível haver DPD sem liberdade de expressão e o exercício do pluralismo de ideias e concepções pedagógicas na escola na relação entre os docentes e destes com os discentes como pretende Programas como o 'Escola Sem Partido'. Os comportamentos, destrezas, conhecimentos, atitudes e valores que constituem a especificidade de ser professor não sobreviverão por muito tempo de forma aceitável, por exemplo, com a vigilância ${ }^{25}$ implacável e

sala de aula sem que tenham curso de licenciatura. Um episódio recente na mídia chamou atenção por reforça à percepção do ensino como bico; trata-se do marketing realizado pela Faculdade Anhanguera que mobilizava interessados em realizar seu curso de "formação pedagógica" por meio de um famoso apresentador de TV com o seguinte chamado: "Tornese professor e aumente sua renda" (SIMPROSP, 2017).

${ }^{25}$ Logo após o resultado das eleições do segundo turno de 2018 e a divulgação da vitória eleitoral de Jair Bolsonaro para presidente do Brasil, a recém-eleita deputada estadual pelo PSL do estado de Santa Catarina, Ana Caroline Campagnolo, faz campanha pela perseguição aos professores "doutrinadores" em rede sociais (JORNALISTAS LIVRES, 2018). 
acirrada de seus adversários políticos educacionais dentro e fora da sala de aula. Ainda que reconheçamos que há muito tempo parte das escolas deixaram de funcionar de forma aceitável devido ao "desmonte"26 de que foram vitimas do governo e da própria sociedade. Entretanto, mais do que em outros ambientes, é na escola que se aprende a conviver com as diferenças, sejam elas de gênero, sexuais, étnicas, etárias, culturais, políticas, econômicas, entre outras. Discentes não são como "tabulas rasa" como pensam os adeptos do Programa acima citado, em que estes apenas assimilam acriticamente os conteúdos programados para serem desenvolvidos na escola pelos professores. Assim, o relacionamento entre profissionalidade com DPD ocorre o tempo todo.

\section{Considerações Finais}

Chegamos ao final de nossa reflexão que se dispôs a analisar os termos professoralidade, profissionalidade, profissionalismo e profissionalização em relação ao DPD. Para sua realização buscamos nos apoiar na pesquisa bibliográfica por meio da leitura e interpretação crítica dos dados e da realidade social e educacional brasileira.

Em nosso entendimento, os termos analisados não podem ser compreendidos se não forem contextualizados, de modo que nos esforçamos no primeiro momento para situar o/a leitor/a diante dos

\footnotetext{
${ }^{26}$ Conforme nota intitulada "O desmonte da escola pública e os efeitos da reforma do Ensino Médio: exclusão, precarização, privatização, desresponsabilização do Estado”, assinada pelas seguintes entidades: Associação Nacional de Pós-Graduação e Pesquisa em Educação (ANPEd); Movimento Nacional em Defesa do Ensino Médio (MNDEM); Associação Nacional pela Formação dos Profissionais da Educação (ANFOPE); Associação Nacional de Política e Administração da Educação (ANPAE); Associação Brasileira de Pesquisa em Educação em Ciências (ABRAPEC); Associação Brasileira de Currículo (ABdC); Associação Nacional de Pesquisa em Financiamento da Educação (FINEDUCA); Centro de Estudos Educação e Sociedade (CEDES); Confederação Nacional dos Trabalhadores em Educação (CNTE); Fórum Nacional de Diretores de Faculdades, Centros de Educação ou Equivalentes das Universidades Públicas Brasileiras (FORUMDIR); Campanha Nacional pelo Direito à Educação; Rede Escola Pública e Universidade (REPU).
} 
Reflexões sobre Professoralidade, Profissionalização, Profissionalidade, Profissionalismo e sua relação com o Desenvolvimento Profissional Docente

desafios no nosso tempo de acordo com o nosso pensamento, sem, contudo, deixar de retomar ao longo do escrito a contextualização em termos mais pormenores, trazendo algumas iniciativas de segmentos sociais do jogo contraditório dos interesses em questão. Nos demos conta, no processo da escrita, que vivemos uma crise sem procedentes de reprodução da sociedade produtora de mercadorias a ponto de nos aproximarmos cada vez mais e de modo virulento ao seu provável colapso, caso a humanidade não consiga superar criativamente a tempo as transformações advindas das inovações que desconsideram o conteúdo do trabalho humano.

Colapso como um dado objetivo, significa, na prática, deixar que valores consagrados pela grande maioria como democracia, igualdade de oportunidade e justiça social, por exemplo, se tornem nada mais do que uma retórica para justificar ações contrárias aos interesses e inclusão da maioria na sociedade. Se alguém ainda não se deu conta das catástrofes humanitárias e naturais em curso, provocada pelos efeitos sobre as pessoas do fetichismo da mercadoria, ainda terá a chance porque nada indica que as iniciativas negativas de destruição das relações entre os seres humanos e destes com a natureza parece que não irão acabar tão cedo.

Quanto aos termos professoralidade, profissionalidade, profissionalismo e profissionalização em relação ao DPD, talvez elas percam o sentido quando o que foi dito acima sobre necessidade de transformações se realizarem, mas por enquanto elas têm validade pelo menos ao lado dos que defendem que a profissão docente cumpra o seu papel com responsabilidade e também com o reconhecimento que merece.

A noção de professoralidade, embora a menos debatida na literatura educacional, está bem próxima da noção de DPD, quando entendida como a razão de ser da profissão e que é paulatinamente constituída sem que nunca se conclua, portanto estão intimamente imbricados na medida em que a profissão docente é entendida como meio e fim de uma formação em permanente desenvolvimento.

Já a profissionalização, esta está longe de ser uma relação espontânea de colaboração e complementariedade mútua com o DPD, 
como ocorre com a categoria professoralidade. Na profissionalização há uma relação problemática em que os dois processos, DPD e profissionalização, podem ocorrer desvinculados um do outro, embora também possa funcionar lado a lado, mas em todo caso reconhecemos que, de modo amplo, a luta pela autonomia e apoio legal perpassa necessariamente pelas questões relacionadas ao DPD.

Em relação ao profissionalismo, vimos que este, por geralmente demandar um certificado de curso superior, anda de mãos dadas como a formação profissional, mas consequentemente exclui aqueles que não se encaixam na cultura das elites, além disto tem-se ainda as reformas educacionais liberais e processuais como meio de controle sobre o professorado e o seu DPD ao estilo 'conta gotas'.

Por fim, a profissionalidade, entendida como a dimensão interna da profissionalização docente, ou seja, é aquilo que faz com que um professor seja o que vem sendo, e é nesta face que se insere o DPD, pois não é possível ser professor sem que conhecimentos, atitudes e habilidades sejam mobilizadas nestes.

Portanto, os argumentos acima evidenciaram que o DPD, na atualidade, perpassa questões da professoralidade, da profissionalidade, do profissionalismo e da profissionalização, mesmo que em intensidades diferentes. Dos quatro termos analisados nesta reflexão, profissionalidade e professoralidade são aqueles que mais dizem respeito a uma estreita vinculação com o desenvolvimento profissional docente por se relacionarem de forma imbricada sem que se possa separar um do outro, ao passo que no profissionalismo e na profissionalização não existe uma relação de complementariedade ou espontânea, mas sem dúvida ambos os lados da relação podem se beneficiar um do outro.

\section{Referências}

AKKARI, Abdeljalil. Internacionalização das políticas educacionais: transformações e desafios. Petrópolis: Vozes, 2011. 
Reflexões sobre Professoralidade, Profissionalização, Profissionalidade, Profissionalismo e sua relação com o Desenvolvimento Profissional Docente

ALVES, Thiago; PINTO, José M. R. Remuneração e características do trabalho docente no Brasil: um aporte. Cadernos de pesquisa. v. 41, n. 43, p.606-639, maio/ago. 2011. Disponível em: <http://www.scielo.br/pdf/cp/v41n143/a14v41n143.pdf>. Acesso: 27 out. 2016. https://doi.org/10.1590/S0100-15742011000200014

ASSOCIAÇÃO DOS PROFESSORES DE ESTABELECIMENTOS DE ENSINO OFICIAL DO CEARÁ (APEOC). Fundeb, piso salarial e carreira do professor da Educação Básica. Fortaleza: Teia digital, maio/2012.

ASSOCIAÇÃO NACIONAL DE PÓS-GRADUAÇÃ E PESQUISA EM EDUCAÇÃO (ANPED). O desmonte da escola pública e os efeitos da reforma do Ensino Médio: exclusão, precarização, privatização, desresponsabilização do Estado. 20 mar. 2018. Disponível em: http://www.anped.org.br/news/o-desmonte-daescola-publica-e-os-efeitos-da-reforma-do-ensino-medio-exclusaoprecarizacao. Acesso em: 26 abr. 2018.

ASSOCIAÇÃO NACIONAL DE PÓS-GRADUAÇÃ E PESQUISA EM EDUCAÇÃO (ANPED). Carta de entidades da Educação contra PL que regulamenta o exercício da profissão de Pedagogo. 17 ago. 2017. Disponível em: http://www.anped.org.br/news/cartade-entidades-da-educacao-contra-pl-que-regulamenta-o-exercicioda-profissao-de-pedagogo. Acesso em: 17 ago. 2017

BAUMAN, Zygmunt. Modernidade líquida. Rio de Janeiro: Zahar, 2001.

BRASIL. Constituição da República Federativa do Brasil. Texto constitucional promulgado em 5 de outubro de 1988, com as alterações determinadas pelas Emendas Constitucionais de Revisão nos 1 a 6/94, pelas Emendas Constitucionais $n^{\circ}$ 1/92 a 91/2016 e pelo Decreto Legislativo $\mathrm{n}^{\mathrm{o}}$ 186/2008. Disponível em: 
$<$ https://www2.senado.leg.br/bdsf/bitstream/handle/id/518231/CF88 Livro_EC91_2016.pdf.> Acesso em: 26 jan. 2018.

BRASIL. Casa civil da Presidência. Lei n. 13.415, de 16 de fevereiro de 2017. Dispõe sobre a reforma do Ensino Médio. Disponível em: < http://www.planalto.gov.br/ccivil_03/_Ato20152018/2017/Lei/L13415.htm>. Acesso em: 26 fev. 2014.

BRASIL. Ministério da Educação. Conselho Nacional da Educação. Resolução n. 2, de $1^{\circ}$ de julho de 2015. Define as Diretrizes Curriculares Nacionais para a formação inicial em nível superior (cursos de licenciatura, cursos de formação pedagógica para graduados e cursos de segunda licenciatura) e para a formação continuada. Disponível em: $<$ http://portal.mec.gov.br/index.php?option=com_docman\&view=do wnload\&alias=70431-res-cne-cp-002-03072015pdf\&category_slug=agosto-2017-pdf\&Itemid=30192 >. Acesso em 26 jan. 2016.

BRASIL, Câmara dos Deputados. Projeto de Lei n. 867/2015. Autor: Deputado Izalci Lucas, 2015. Disponível em: <http://www.camara.gov.br/sileg/integras/1317168.pdf>. Acesso em: 26 jan. 2016.

BRASIL. Casa civil da Presidência. Decreto n. 7.219, de 24 de junho de 2010. Dispõe sobre o Programa Institucional de Bolsa de Iniciação à Docência - Pibid e dá outras providências. Disponível em: <http://www.planalto.gov.br/ccivil_03/_ato20072010/2008/lei/111738.htm>. Acesso em: 26 fev. 2014.

BRZEZINSKI, Iria. Introdução. In: (Org.). Profissão professor: identidade e profissionalização docente. Brasília: Plano, 2002. p.7-19. 
Reflexões sobre Professoralidade, Profissionalização, Profissionalidade, Profissionalismo e sua relação com o Desenvolvimento Profissional Docente

CARLSSON, Chris. Nowtopia: iniciativas que estão construindo o futuro hoje. Porto Alegre: Tomo Editorial, 2014.

CEARÁ. Lei n. 10.884, de 1984. Estatuto do Magistério Oficial do Estado. 1984a. Disponível em: <https://www.apeoc.org.br/.../ESTATUTO_DO_MAGISTERIO_OF ICIAL_DO_ESTADO_FINALIZADO.doc>. Acesso em: 26 jan. 2016.

CONTRERAS, José. A autonomia de professores. 2. ed. São Paulo: Cortez, 2012.

ESTEVES, Manuela et. al. Para pensar a educação em Portugal: a formação de professores. 2012. Disponível em: <http://fundacaobetania.org/ges/Educacao2015/actualizacoes/actualizacao_PENSAR A_EDUCACAO_Formacao_de_Professores.pdf>. Acesso em: 26 jan. 2017.

FARIAS, Isabel M. S.; ROCHA, Cláudio C. T. Desenvolvimento profissional de professores da educação básica: reflexões a partir da experiência no PIBID. In: Revista Reflexão e Ação, Santa Cruz do Sul, v. 24, n. 3, p.123-140, Set./Dez. 2016. Disponível em: http://online.unisc.br/seer/index.php/reflex/index. Acesso em: 26 jan. 17. https://doi.org/10.17058/rea.v24i3.7524

FERREIRA, Liliana S. Professoras e professores como autores de sua professoralidade: a gestão do pedagógico na sala de aula. RBPAE, Porto Alegre, RS, v.25, n.3, p. 425-438, set./dez. 2009.

FREIDSON, Eliot. Renascimento do Profissionalismo: teoria, profecia e política. São Paulo: Edusp, 1998.

HAGUETTE, André. Educação: bico, vocação ou profissão? In: - A luta pelo ensino básico: uma proposta pedagógica administrativa. Fortaleza: Edições UFC, 1990. p. 39-52. 
JAPPE, Anselm. Crédito à morte: a decomposição do capitalismo e suas críticas. São Paulo: Hedra, 2013.

JORNALISTAS LIVRES. Deputada eleita do PSL faz campanha pela perseguição política de professores em sala. 29 out. 2018. Disponível em: <https://jornalistaslivres.org/deputada-eleita-do-pslfaz-campanha-pela-perseguicao-politica-de-professores-em-sala-deaula/>. Acesso em: 24 jan. 2019.

KURZ, Robert. $O$ colapso da modernização: da derrocada do socialismo de caserna à crise econômica mundial. 2. ed. São Paulo: Paz e terra, 1992.

LIBÂNEO, José C. Adeus professor, adeus professora: novas exigências educativas e profissão docente. 13. ed. São Paulo: Cortez, 2011.

LOPES, Sônia C. Obreiros do progresso ou párias da sociedade? Professores na imprensa pedagógica em fins do século XIX. In: CARDOSO, Tereza F. L. (Org.). História da profissão docente no Brasil e em Portugal. Rio de Janeiro: Maud X; FAPERJ, 2014. p. 79-100.

MARQUES, Luiz. Capitalismo e colapso ambiental. Campinas: Editora da Unicamp, 2015.

MATTAR, João. Tutoria e interação em educação a distância. São Paulo: Cengage Learning, 2012

MENDES, Emanoela T. B.; FARIAS, Isabel M. S.; THERRIEN, Silvia M. N. Trabalhando com materiais diversos e exercitando o domínio da leitura: a pesquisa bibliográfica e a pesquisa documental. In: THERRIEN, Silvia M. N.; FARIAS, Isabel M. S.; NUNES, João 
Reflexões sobre Professoralidade, Profissionalização, Profissionalidade, Profissionalismo e sua relação com o Desenvolvimento Profissional Docente

B. (Orgs.). Pesquisa científica para iniciantes: caminhando no labirinto. Métodos de pesquisa. Fortaleza: EdUECE, 2011.p. 25-53

MINISTÉRIO PÚBLICO FEDERAL. PROCURADORIA FEDERAL DOS DIREITOS DO CIDADÃO (MPF/PFDC). Nota Técnica 01/2016. Disponível em: <http://pfdc.pgr.mpf.mp.br/temasde-atuacao/educacao/saiba-mais/proposicoes-legislativas/notatecnica-01-2016-pfdc-mpf>. Acesso em: 26 jan. 2017

MOROSINI, Marilia C. (Editora-chefe). Enciclopédia de Pedagogia Universitária. Brasília: INEP/RIES, 2006. v 2, p. 400.

NÓVOA, António. Formação de professores e profissão docente. In: (Coord.). Os professores e sua formação. 2. ed. Lisboa: Dom Quixote, 1995. p. 15-34.

NUÑEZ, Isauro B.; RAMALHO, Betânia L. A profissionalização da docência: um olhar a partir da representação de professoras do ensino fundamental. Revista Iberoamericana de Educación, Madri, Espanha, v. 46, n. 9, p. 1-13, 2008. Disponível em: <https://rieoei.org/RIE/article/view/1872>. Acesso em: 26 jan. 2016.

PESSANHA, Eurize C. Ascensão e queda do professor. 3. ed. São Paulo: Cortez, 2001.

POPKEWITZ, Thomas. Profissionalização e formação de professores: algumas notas sobre a sua história, ideologia e potencial. In: NÓVOA, António (Coord.). Os professores e sua formação. 2. ed. Lisboa, Dom Quixote, 1995. p. 35-50.

PREFEITURA MUNICIPAL DE FORTALEZA (PMF0. Lei $n$. 5.895, de 13 de novembro de 1984. Estatuto do Magistério do Município de Fortaleza. Disponível em: <http://sindiute.org.br/wpcontent/uploads/2014/07/estatuto_do_magisterio.pdf>. Acesso em: 26 jan. 2017. 
RAMALHO, Betânia R; NUÑES, Isauro B; GAUTHIER, Clermont. Formar o professor, profissionalizar o ensino: perspectiva e desafios. Porto Alegre: Sulina, 2003.

ROCHA, Cláudio C. Torquato. Narrativas de professores em situação de desenvolvimento profissional: estudo no contexto do PIBID. Tese de Doutorado em Educação. Fortaleza: Universidade Estadual do Ceará, 2018.

SACRISTÁN, José G. Consciência e acção sobre a prática como libertação profissional dos professores. In: NÓVOA, António (Org.). Profissão professor. Porto: Porto Editora, 1991. p. 61-92.

SANTOS, Boaventura de Souza. Um discurso sobre as ciências. 16. ed. Porto: Edições Afrontamento, 2010.

. Da ciência moderna ao novo senso comum. In: - A crítica da razão indolente: contra o desperdício da experiência. 4. ed. São Paulo: Cortez, 2002. p. 55-117.

- Introdução a uma ciência pós-moderna. Rio de Janeiro: Graal, 1989.

SINDICATO DOS PROFESSORES DE SÃO PAULO (SINPROSP). Protesto faz Anhanguera retirar propaganda de mau gosto. 22 ago. 2017. Disponível em:< http://www.sinprosp.org.br/noticias.asp?id_noticia=2811>. Acesso em: 22 ago. 2017

SCHWAB, Klaus. A quarta revolução industrial. São Paulo: Edipro, 2016. 
Reflexões sobre Professoralidade, Profissionalização, Profissionalidade, Profissionalismo e sua relação com o Desenvolvimento Profissional Docente

TARDIF, Maurice. A crise do profissionalismo. In:__. Saberes docentes e formação profissional. 10. ed. Petrópolis: Vozes, 2010. p. 250-254.

VEIGA, Ilma P. A; ARAÚJO, José C. KAPUZINIAK, Célia. Docência: uma construção ético-profissional. Campinas: Papirus, 2005.

VICENTINI, Paula P; LUGLI, Rosário G. História da profissão docente no Brasil: representações em disputa. São Paulo: Cortez, 2009.

Data de registro: 04/02/2020

Data de aceite: $28 / 08 / 2020$ 